\title{
Model Peramalan Garis Kemiskinan Menggunakan Metode Double Exponential Smoothing dari Holt
}

\author{
Roni Aminudin ${ }^{1}$, Yeffry Handoko ${ }^{2}$ \\ ${ }^{1,2}$ Jurusan Magister Sistem Informasi UNIKOM \\ Jl. Dipati Ukur No. 112-116, Bandung, Jawa Barat, Indonesia \\ ${ }^{1}$ roniwaz@gmail.com \\ ${ }^{2}$ yeffryhp@unikom.ac.id
}

\begin{abstract}
Abstrak - Penelitian ini bertujuan untuk melakukan peramalan Garis Kemiskinan untuk membantu pemerintah mendapatkan informasi yang akurat dan cepat. Metode yang digunakan dalam penelitian ini adalah Double Exponential Smoothing dari Holt. Metode ini adalah bagian dari data berdasarkan analisis deret waktu (time series). Penelitian ini menerapkan teori peramalan untuk menghasilkan ramalan Garis Kemiskinan untuk tahun yang akan datang. Selanjutnya, penelitian ini melakukan analisa pola data, dan menentukan nilai parameter terbaik. Metode Double Exponential Smoothing dari Holt menggunakan parameter Alpha $(\alpha)$ dan Gamma $(\gamma)$. Untuk menentukan nilai parameter terbaik adalah menggunakan metode trial dan error. Nilai parameter terbaik menghasilkan nilai MAPE (Mean Absolute Percentage Error) terkecil. Pola data menunjukan trend, berarti metode Double Exponential Smoothing dari Holt tepat untuk digunakan dalam penelitian ini. Nilai parameter yang dihasil dari metode trial dan error adalah Alpha $(\alpha)$ sebesar 0,7 dan Gamma $(\gamma)$ sebesar 0,1 yang menghasilkan ukuran akurasi terkecil, dalam penelitian ini menggunakan MAPE. Dengan mengamati hasil peramalan yang telah dilakukan, model peramalan ini memiliki kinerja yang sangat baik. Nilai Garis Kemiskinan akan terus meningkat, sesuai dengan pola konsumsi yang meningkat dan kenaikan harga kebutuhan pokok.
\end{abstract}

Kata kunci : Garis Kemiskinan, Peramalan, Double Exponential Smoothing dari Holt, Time serie, MAPE (Mean Absolute Percentage Error).

Abstract-This research aims to forecast the poverty line, to help a government obtain accurate and fast information. The method used in this research is Double Exponential Smoothing Holt's Method. This method is a part of the data based time series analysis. The research applies the forecasting theory to produce a poverty line forecast for the coming year. Next, this research is analysing data patterns and determine the parameter values. Double Exponential Smoothing Holt's Method uses the parameters Alpha $(\alpha)$ and Gamma $(\gamma)$. To determine the best parameter value is to use the trial and error method. The best parameter value produces the smallest value of MAPE (Mean Absolute Percentage Error). The data pattern shows the trend, meaning that the Double Exponential Smoothing Holt's method is appropriate for use in this research. The parameter values generated from the trial and error methods are Alpha ( $a)$ of 0.7 and Gamma $(\gamma)$ of 0.1, which produced the smallest measure of accuracy, in this research using MAPE. By observing the results of the forecasting that has been done, this forecasting model has a very good performance. Poverty Line value will keep increasing, in accordance with increasing consumption patterns and rising prices of basic necessities.

Keywords :Poverty Line, Forecasting, Double Exponential Smoothing Holt's Method, Time Series, MAPE (Mean Absolute Percentage Error).

\section{Pendahuluan}

Kemiskinan adalah masalah multidimensi yang kompleks, bukan hanya diukur dari pendapatan tetapi juga melibatkan kerentanan dan kerentanan orang atau sekelompok orang baik laki-laki maupun perempuan menjadi miskin [10]. Untuk mengukur kemiskinan, Badan Pusat Statistik (BPS) menggunakan kemampuan untuk memenuhi kebutuhan dasar. Kemiskinan dipandang sebagai ketidakmampuan ekonomi untuk memenuhi kebutuhan dasar makanan dan non-makanan yang diukur dari pengeluaran. Penanggulangan kemiskinan dan ketidaksetaraan dalam distribusi pendapatan adalah inti dari semua masalah pembangunan dan merupakan tujuan utama kebijakan pembangunan di banyak negara [17]. Masalah kemiskinan merupakan salah satu masalah mendasar yang menjadi pusat perhatian pemerintah di negara mana pun. Komitmen dunia internasional dalam penanggulangan kemiskinan tercantum dalam Sustainable Developmeny Goals (SDGs) sebagai kelanjutan dari Millenium Development Goals (MDGs) yang disepakati oleh 193 negara pada bulan September 2015. Berbagai program pengentasan kemiskinan telah dilakukan, seperti bantuan tunai untuk masyarakat "top down" hingga program pemberdayaan masyarakat lain. Salah satu 
aspek penting untuk mendukung strategi penanggulangan kemiskinan adalah ketersediaan data dan informasi yang akurat dan "tepat sasaran" mengenai kemiskinan. Pengukuran kemiskinan yang dapat dipercaya dapat menjadi instrumen yang tangguh bagi para pengambil kebijakan dalam memfokuskan perhatian pada kondisi kehidupan orang miskin. Angka kemiskinan yang baik dapat digunakan untuk mengevaluasi kebijakan pemerintah dalam upaya penanggulangan kemiskinan, membandingkan kemiskinan antar waktu dan wilayah, dan menentukan target penduduk miskin dengan tujuan memperbaiki kondisi mereka.

Ada banyak metode-metode yang digunakan dalam mengukur kemiskinan di suatu daerah. Menurut BPS, orang miskin adalah penduduk yang memiliki rata-rata pengeluaran per kapita per bulan di bawah garis kemiskinan [3]. Untuk mengukur kemiskinan di Indonesia. BPS menggunakan konsep kemampuan kebutuhan dasar (basic need approach), dengan pendekatan ini, kemiskinan dipandang sebagai ketidakmampuan dari sisi untuk memenuhi kebutuhan dasar baik makanan dan nonmakanan yang diukur dari segi pengeluaran [3]. Bank Dunia dalam mengukur kemiskinan adalah tercapainya kehidupan yang layak dengan penghasilan US \$ 1 per hari per kapita.

Garis kemiskinan adalah representasi dari jumlah minimum rupiah yang dibutuhkan untuk memenuhi kebutuhan makanan pokok minimum yang setara dengan 2100 kilo kalori per kapita per hari dan bahan pokok bukan makanan [3].

Salah satu sebab kurangnya penanggulangan kemiskinan pada suatu wilayah karena kurangnya informasi mengenai kemiskinan. Untuk itu diperlukan suatu metode untuk mengetahui keberadaan kemiskinan di masa yang akan datang, sebagai upaya penanggulangan kemiskinan di suatu daerah. Berdasarkan latar belakang di atas, maka diperlukan suatu penelitian tentang peramalan Garis Kemiskinan untuk yang akan datang, sebagai peringatan dini pemerintah dalam penanggulangan masalah kemiskinan, karena Garis Kemiskinan merupakan variabel yang digunakan untuk menghitung jumlah penduduk miskin. Tujuan dari penelitian ini adalah "Melakukan peramalan Garis Kemiskinan dengan menggunakan Metode Double
Exponential Smoothing dari Holt". Metode yang digunakan untuk data yang bersifat trend linier yang menunjukkan persamaan garis lurus yang terbentuk berdasarkan titik-titik diagram pencar dari data selama periode waktu tertentu. Model trend biasanya digunakan untuk memprediksi perkiraan jangka panjang.

Peramalan adalah seni dan ilmu untuk memprediksi peristiwa masa depan. Peramalan mungkin melibatkan mengambil data historis dan memproyeksikannya ke masa depan dengan semacam model matematika. Ini mungkin prediksi subyektif atau intuitif [2].

Salah satu metode yang digunakan dalam melakukan peramalan dengan menganalisa data dengan model time series adalah metode Double Exponential Smoothing. Metode ini dibagi menjadi dua yaitu Double Exponential Smoothing satu parameter dari Brown dan Double Exponential Smoothing dari Holt. Double Exponential Smoothing dari Brown merupakan model linear yang di kemukakan oleh Brown. Didalam metode ini dilakukan proses smoothing dua kali. Metode ini dapat dihitung dengan tiga nilai data dan satu parameter yaitu alpha. Pendekatan ini juga memberikan bobot yang semakin menurun pada observasi masa lalu. Double Exponential Smoothing dari Holt pada prinsipnya sama dengan Brown, Tapi Holt tidak menggunakan rumus Double Exponential Smoothing secara langsung. Sebagai gantinya Holt memuluskan nilai trend dengan parameter yang berbeda dari parameter yang digunakan pada deret asli. Model peramalan dari Double Exponential Smoothing dari Holt didapat dengan menggunakan dua parameter pemulusan yaitu alpha dan gamma.

Model peramalan ini menggunakan metode Double Exponential Smoothing dari Holt. Langkah pertama dalam peramalan dengan metode Double Exponential Smoothing dari Holt adalah memplot data terlebih dahulu untuk mengetahui pola data. Langkah kedua adalah estimasi atau penentuan parameter yaitu alpha $(\alpha)$ dan gamma $(\gamma)$. Parameter alpha $(\alpha)$ digunakan untuk menghaluskan data asli secara berkala sambil menghaluskan trend. Metode ini menggunakan dua parameter alpha dan gamma. dalam penelitian ini nilai parameter terbaik yang dihasilkan yaitu alpha $=0,7$ dan gamma $=0,1$ yang menghasilkan nilai MAPE terkecil.. Langkah 
selanjutnya adalah meramalkan data untuk tahun mendatang. Hasil peramalan Garis Kemiskinan akan terus meningkat karena perubahan pola konsumsi dan kenaikan harga kebutuhan pokok. Model peramalan dapat digunakan sebagai alat bagi pemerintah dan pemangku kepentingan lainnya dalam perencanaan dan kebijakan dalam mengurangi kemiskinan jangka pendek dan jangka panjang.

Tujuan dari penelitian ini adalah untuk meramalkan Garis Kemiskinan di Jawa Barat menggunakan metode Double Exponential Smoothing dari Holt, sebagai referensi data dan informasi untuk perencanaan dalam rangka pengentasan kemiskinan dan mengetahui kinerja model peramalan Garis Kemiskinan dengan menggunakan metode Double Exponential Smoothing dari Holt.

\section{Metodologi Penelitian}

Metode yang digunakan dalam penelitian ini adalah metode deskriptif, yaitu metode yang berfokus pada penyelesaian masalah. Dalam penelitian ini, penulis menggunakan metode pendekatan penelitian kuantitatif. Metode kuantitatif yaitu metode yang menyajikan data yang didominasi dalam bentuk angka dan analisis data yang menggunakan statistik. Dengan pendekatan statistik, dalam penelitian ini menggunakan metode Double Exponential Smoothing. Metode ini digunakan ketika data menunjukkan trend. Tingkatan eksponensial dengan fungsi trend seperti tingkatan sederhana kecuali bahwa dua komponen harus diperbarui pada setiap periode dan level trend. Taksiran tingkat estimasi data disempurnakan pada akhir setiap periode. Trend ini merupakan perkiraan pertumbuhan rata-rata yang lancar pada akhir periode [13]. Ada dua metode dalam Double Exponential Smoothing, yaitu metode Double Exponential Smoothing dari Brown dan metode Double Exponential Smoothing dari Holt. Dalam penelitian ini, penulis menggunakan metode Double Exponential Smoothing dari Holt.

Dalam penelitian ini, penulis memilih Provinsi Jawa Barat sebagai tempat penelitian. Data yang digunakan dalam penelitian ini adalah data sekunder, yaitu data Garis Kemiskinan di Jawa
Barat periode 2005-2017. Jenis data yang digunakan dalam penelitian ini adalah data time series dan data cross section atau sering disebut data panel. Keseluruhan data yang digunakan dalam penelitian ini diperoleh dari BPS Provinsi Jawa Barat.

\section{HASIL DAN PEMBAHASAN}

Penelitian ini menggunakan metode Double Exponential Smoothing dari Holt. Metode ini tidak menggunakan beberapa rumus penghalusan secara langsung, sebagai gantinya, Holt menghaluskan nilai trend dengan parameter yang berbeda dari dua parameter yang digunakan dalam seri asli [9].

Dalam penelitian ini, data yang digunakan untuk peramalan adalah data sekunder yaitu data Garis Kemiskinan tahun 2005 - 2017 di Jawa Barat, data tersebut diperoleh dari BPS Provinsi Jawa Barat. Data dapat dilihat pada tabel IV.1.

TABEL IV.1

GARIS KEMISKINAN DI JAWA BARAT TAHUN 2005-2017

\begin{tabular}{|c|c|}
\hline Periode & $\begin{array}{c}\text { Garis Kemiskinan } \\
\text { (Rupiah) }\end{array}$ \\
\hline 2005 & 133.701 \\
\hline 2006 & 149.673 \\
\hline 2007 & 165.734 \\
\hline 2008 & 190.788 \\
\hline 2009 & 220.068 \\
\hline 2010 & 201.138 \\
\hline 2011 & 226.097 \\
\hline 2012 & 242.104 \\
\hline 2013 & 276.825 \\
\hline 2014 & 291.474 \\
\hline 2015 & 306.876 \\
\hline 2016 & 324.992 \\
\hline 2017 & 344.427 \\
\hline
\end{tabular}

Tabel IV.1 merupakan data Garis Kemiskinan Provinsi Jawa Barat periode 2005-2017 yang merupakan rekapitulasi dan nilai rata-rata Garis Kemiskinan dari 27 Kabupaten dan Kota di Jawa Barat. Dilihat dari data tersebut diduga pola data Garis Kemiskinanan mempunyai pola trend, sehingga peneliti menggunakan metode Double Exponential Smoothing dalam penelitian ini. 
Metode yang digunakan dalam peramalan menggunakan metode Double Exponential Smoothing dari Holt. Langkah pertama dalam peramalan dengan metode Double Exponential Smoothing dari Holt adalah melakukan plot data terlebih dahulu untuk mengetahui pola data. Tahap ini bertujuan untuk menentukan trend, siklus, musiman, random (acak) atau stasioner.

Hasil penggambaran pola data time series dari data aktual dibuat plot dan hasilnya disajikan dalam Gambar 1. Plot data Garis Kemiskinan di Jawa Barat tahun 2005-2017

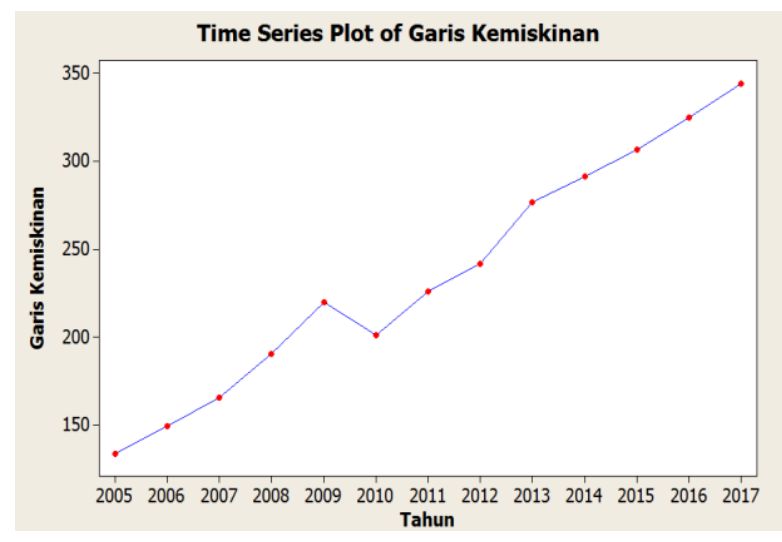

Gambar 4.1. Time series Plot Data Garis Kemiskinan .

Gambar 4.1 menunjukkan bahwa pola Garis Kemiskinan menunjukkan pola data adalah trend linier, sehingga metode yang baik dan tepat untuk digunakan adalah metode Double Exponential Smoothing dari Brown dan metode Double Exponential Smoothing dari Holt. Peneliti memutuskan metode yang digunakan dalam penelitian ini menggunakan metode Double Exponential Smoothing dari Holt. Metode ini menggunakan dua parameter smoothing alpha $(\alpha)$ dan gamma $(\gamma)$, dalam menghaluskan data trend linier. Metode Double Exponential Smoothing dari Holt tidak menggunakan beberapa rumus smoothing secara langsung.

Langkah kedua adalah estimasi atau penentuan parameter yaitu alpha $(\alpha)$ dan gamma $(\gamma)$. Parameter alpha $(\alpha)$ digunakan untuk menghaluskan data asli secara berkala sambil menghaluskan trend. Nilai parameter antara 0 dan 1. Menentukan nilai parameter ini dapat dilakukan dengan cara trial dan error. Parameter ini menentukan perbedaan antara nilai perkiraan dan data aktual. Ketika nilai alpha mendekati 1, bobot yang diberikan pada data terbaru lebih besar sehingga efek smoothing kecil. Sebaliknya, ketika nilai alpha mendekati 0 , itu akan memberikan respons kecil terhadap data terbaru, sehingga efek smoothingnya besar.

Penentuan parameter alpha $(\alpha)$ dan gamma $(\gamma)$ dalam praktiknya hanya mengambil kisaran nilai yang terbatas, walaupun secara teoritis alpha $(\alpha)$ dan gamma $(\gamma)$ dapat dianggap bernilai 0 dan 1 . Karena adanya himpunan pilihan alpha $(\alpha)$ dan gamma $(\gamma)$, yang dipersempit, maka metode Double Exponential Smoothing biasanya dilihat sebagai metode yang lebih mudah diterapkan [9]. Parameter gamma $(\gamma)$ digunakan untuk menghilangkan sedikit fleksibilitas dalam data yang dihasilkan selama perkiraan. Dengan menggunakan metode trial dan error untuk menentukan nilai parameter alpha $(\alpha)$ dan gamma $(\gamma)$ yang optimal yaitu menghasilkan nilai MAPE yang paling kecil. Dari hasil pengolahan data menggunakan program komputer (software minitab) nilai alpha $=0,7$ dan gamma 0,1 menghasilkan nilai MAPE terkecil yaitu 3,005\%. Untuk lebih jelasnya dapat di lihat pada table IV.2

TABEL IV.2

PARAMETER DAN AKURASI PENGUKURAN

\begin{tabular}{|c|c|r|r|l|}
\hline $\begin{array}{c}\text { Parameter } \\
\alpha\end{array}$ & $\begin{array}{c}\text { Parameter } \\
\gamma\end{array}$ & \multicolumn{1}{c|}{ MAPE } & \multicolumn{1}{c|}{ MAD } & \multicolumn{1}{l|}{ MSD } \\
\hline 0,1 & 0,1 & 3,0625 & 6,9121 & 86,9956 \\
\hline 0,2 & 0,1 & 3,2344 & 7,3403 & 96,0212 \\
\hline 0,3 & 0,1 & 3,307 & 7,492 & 104,069 \\
\hline 0,4 & 0,1 & 3,289 & 7,394 & 111,347 \\
\hline 0,5 & 0,1 & 3,204 & 7,120 & 118,275 \\
\hline 0,6 & 0,1 & 3,100 & 6,817 & 125,210 \\
\hline 0,7 & 0,1 & 3,005 & 6,560 & 132,469 \\
\hline 0,8 & 0,1 & 3,020 & 6,555 & 140,459 \\
\hline 0,9 & 0,1 & 3,226 & 7,092 & 149,795 \\
\hline
\end{tabular}

Dalam penelitian ini, pengukuran akurasi peramalan menggunakan nilai MAPE. Nilai MAPE adalah ukuran akurasi relatif untuk menentukan persentase penyimpangan hasil peramalan, ini menunjukkan bahwa nilai MAPE menghasilkan persentase kesalahan dari hasil peramalan.

Langkah ketiga adalah pengolahan data Garis Kemiskinan pada tabel 4.1. Hasil pengolahan data menghasilkan nilai angka ramalan dapat dilihat pada tabel IV.3. 
TABEL IV. 3

HASIL PENGOLAHAN DATA GARIS KEMISKINAN MENGGUNAKAN METODE DOUBLE EXPONENTIAL SMOOTHING DARI HOLT (RUPIAH), TAHUN 2005-2017

\begin{tabular}{|c|c|c|c|c|}
\hline Tahun & $\begin{array}{c}\text { Garis } \\
\text { Kemiskinan }\end{array}$ & Smooth & Predict & Selisih \\
\hline 2005 & 133.701 & 133.254 & 132.210 & 1.4910 \\
\hline 2006 & 149.673 & 149.991 & 150.732 & -1.0590 \\
\hline 2007 & 165.734 & 166.232 & 167.395 & -1.6609 \\
\hline 2008 & 190.788 & 188.608 & 183.520 & 7.2678 \\
\hline 2009 & 220.068 & 215.969 & 206.404 & 13.6637 \\
\hline 2010 & 201.138 & 211.213 & 234.722 & -33.5840 \\
\hline 2011 & 226.097 & 226.553 & 227.615 & -1.5184 \\
\hline 2012 & 242.104 & 242.327 & 242.848 & -0.7445 \\
\hline 2013 & 276.825 & 271.349 & 258.571 & 18.2538 \\
\hline 2014 & 291.474 & 290.693 & 288.870 & 2.6035 \\
\hline 2015 & 306.876 & 307.332 & 308.397 & -1.5208 \\
\hline 2016 & 324.992 & 324.973 & 324.930 & 0.0624 \\
\hline 2017 & 344.427 & 343.871 & 342.575 & 1.8519 \\
\hline
\end{tabular}

Tabel IV.3 menunjukkan hasil pengolahan peramalan Garis Kemiskinan untuk periode 2005 2017 di mana nilai pendekatan peramalan pada setiap periode menunjukkan trend yang meningkat, akurasi nilai peramalan dapat dilihat dari nilai peramalan yang mendekati nilai aktualnya. Nilai peramalan yang paling mendekati dengan nilai aktualnya adalah pada tahun 2016 yaitu Rp. 62,4, sedangkan nilai peramalan dengan selisihnya besar adalah pada tahun 2010 di mana nilai error atau salah dalam perhitungannya adalah Rp. $(33,580)$.

Sedangkan nilai peramalan untuk waktu yang akan datang, yaitu perkiraan untuk periode 2018 2020, dapat dilihat pada tabel IV.4

TABEL IV.4

\begin{tabular}{|c|c|c|c|}
\hline Periode & $\begin{array}{c}\text { Hasil Peramalan } \\
(\mathrm{Rp} .)\end{array}$ & $\begin{array}{c}\text { Lower } \\
(\mathrm{Rp})\end{array}$ & $\begin{array}{c}\text { Upper } \\
(\mathrm{Rp})\end{array}$ \\
\hline 2018 & 361.603 & 345.531 & 377.675 \\
\hline 2019 & 379.334 & 359.043 & 399.625 \\
\hline 2020 & 397.066 & 372.189 & 421.942 \\
\hline
\end{tabular}

Tabel IV. 4 menunjukan nilai peramalan untuk tahun yang akan dating, dimana Garis Kemiskinan terus meningkat setiap tahun, hal ini disebabkan karena Garis Kemiskinan dipengaruhi oleh pola konsumsi dan kenaikan harga kebutuhan pokok, sehingga pengeluaran akan terus meningkat.

Langkah selanjutnya adalah membuat plot peramalan Garis Kemiskinan yang ditunjukkan pada Gambar 4.3.

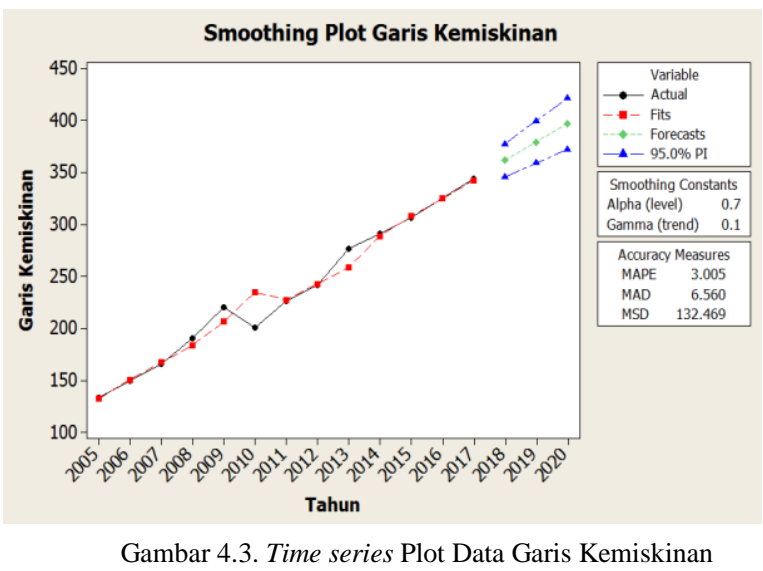

Gambar 4.3, menunjukkan variabel actual, fits, forecast, dan $95 \%$ PI. Grafik ini mencerminkan smoothing costant Alpha ( $\alpha)$ 0,7 dan Gamma $(\gamma)$ 0,1. Nilai Ukuran Akurasi dari MAPE, MAD, dan MSD juga disajikan. Keakuratan MAPE 3,005\%, MAD 6,650 dan MSD 132,469. Suatu model memiliki kinerja yang sangat baik jika nilai MAPE di bawah $10 \%$, dan memiliki kinerja yang baik jika nilai MAPE antara $10 \%$ dan $20 \%$ [18].

Analisis model peramalan Garis kemiskinan, dimana pola data memiliki trend linier, sehingga metode Double Exponential Smoothing dari Holt sangat tepat untuk digunakan. Parameter optimal yang dihasilkan dengan menggunakan metode trial dan error adalah alpha $=0,7$ dan gamma $=0,1$ dengan hasil nilai MAPE 3,005\%. Nilai MAPE tersebut menunjukkan persentase kesalahan peramalan sebesar 3,005\%, dengan nilai MAPE di bawah $10 \%$, model peramalan ini memiliki kinerja yang sangat baik. Nilai Garis Kemiskinan untuk tahun yang akan datang terus menunjukkan peningkatan setiap tahun dan pola datanya trend 
linear. Adapun Faktor-faktor yang mempengaruhi nilai kenaikan Garis Kemiskinan adalah pola konsumsi masyarakat, tingginya tingkat inflasi karena kenaikan harga, terutama komoditas untuk kebutuhan dasar, dan fenomena kebijakan pemerintah dalam bidang ekonomi. Model peramalan ini dapat digunakan untuk jangka panjang karena model ini menghasilkan kesalahan ramalan sebesar 3,005\% sesuai dengan nilai MAPE. Model peramalan diharapkan dapat digunakan sebagai alat bagi pemerintah dan pemangku kepentingan lainnya dalam perencanaan dan kebijakan dalam mengurangi kemiskinan dalam jangka pendek dan panjang.

\section{KESIMPULAN}

Diperlukan pemanfaatan sistem informasi untuk memproses data dan informasi yang membantu pemerintah dan pemangku kepentingan dalam konteks pengentasan kemiskinan. Peramalan Garis Kemiskinan sangat berguna untuk mengetahui situasi masa depan terkait kemiskinan. sehingga pemerintah dan pemangku kepentingan dapat mengantisipasi fenomena yang dapat mempengaruhi peningkatan garis kemiskinan. model ini adalah model yang tepat digunakan dalam peramalan garis kemiskinan di mana penyimpangan peramalan sangat kecil, yaitu di bawah $10 \%$, ini menunjukkan kinerja yang sangat baik.

\section{REFERENSI}

[1] Ahmad Nazim Aimran. 2014. A Comparison between single exponential smoothing (SES), double exponential smoothing (DES), holt's (brown) adaptive response rate exponential smoothing (ARRES) technique inforecasting Malaysia population. Malaysia : Global Journal of Mathematical Analysis.

[2] Barry, Render dan Jay Heizer. 2001. Prinsip-prinsip Manajemen Operasi: Operations Management. Jakarta : Salemba Empat.

[3] BPS. 2008. Analisis dan Penghitungan Tingkat Kemiskinan, Jakarta, Indonesia : Badan Pusat Statistik.

[4] BPS Provinsi Jawa Barat. 2018. Kemiskinan Kabupaten/Kota di Jawa Barat 2012-2017. Jawa Barat, Indonesia.

[5] Chang, Pei-Chan, Yen-Wen Wang, and Chen-Hao Liu. 2017. The Development of Weight for PCB Sales Forecasting. Elsevier 32 (Expert Sysytem with Aplications).

[6] Dielman, T. E. 2006. Choosing Smoothing Parameters for Exponential Smoothing : Minimizing Sums of Squared versus Sums Of Absolute Errors. Journal of Modern Applied Statistical Methods.

[7] Li, Xiaochen. 2013. Comparison and Analysis between Holt Exponential Smoothing and Brown Exponential Smoothing Used for Freight Turnover Forecasts. Third International Conference on Intelligent System Design and Engineering Applications.
[8] Makridakis, Sypros, Steven C, Wheelwright, and Rob J. Hyndman 1989. Forecasting : Methods and Aplications. Third edition, John Wiley and Sons.

[9] Makridakis, S., Wheelwright, S.C., \& McGee, VE. 1999. Metode dan Aplikasi Peramalan. Diterjemahkan oleh Sumitro, H. Jakarta : Binarupa Aksara.

[10] Mega F. 2003. Strategi Bersama Masyarakat Sipil Indonesia : Empa Pilar Demokratisasi untuk Melawan Kemiskinan dan Pemiskinan. Jakarta : Gerakan Anti Pemiskinan (GAPRI).

[11] Nurkse, Ragnar. 1953. Problems of Capital Formation in Underdevelop Countries.

[12] Paul, S.K., 2011. Determination of Exponential Smoothing Constant to Minimize Mean Square Error and Mean Absoute Deviation. Global Journal of Research in Engineering.

[13] Prajakta S. Kalekar. 2004. Time series forecasting using Holt's Winters Exponential Smoothing. Kanwal Rekhi School of Information Technology.

[14] Sri Winarso dan Martin Setiawan. 2013. Model Time Series Peramalan Daerah Miskin menggunakan Double Exponential Smoothing berbasis Metode Fuzzy MCDA, Salatiga, Indonesia.

[15] Taylor, J. W. 2003. Short Term Electricity Demand Forecasting Using Double Exponential Smoothing . Journal of Operatioan Research, Volume 54 799-805.

[16] Todaro, M 1985. Economic Development in The Third World, Longman

[17] Todaro, Michael P. and Stephen C. Smith. 2006. Economic Development (Ninth Edition, volume I). Jakarta: Erlangga.

[18] Zainun, N.Y dan Majid, ZA. 2003. Low Cost Demand Predictor. Malaysia. Universitas Teknologi Malaysia. 